\title{
PATHOGENICITY OF ACHOLEPLASMA OCULI FOR FEMALE GENITAL TRACT OF GOATS
}

\author{
C. J. SHARMA, P. P. GUPTA and H. S. BANGA \\ Department of Veterinary Pathology, Punjab Agricultural University, Ludhiana 141 004, India
}

Received August 24, 1990

\begin{abstract}
Sharma C. J., P. P. Gupta, H. S. Banga: Pathogenicity of Acholeplasma oculi for Female Genital Tract of Goats. Acta vet. Brno, 60, 1991: 289-295.

To study the pathogenicity of Acholeplasma oculi for female genital system of goats, 8 apparently healthy kids were taken. Two $\mathrm{ml}$ of $A$. oculi (19-L strain) culture containing $8 \times 10^{6} \cdot \mathrm{ml}^{-1} \mathrm{CFU}$ (colony forming units) was inoculited into scarified vulva and vagina of 7 kids, while $2 \mathrm{ml}$ of sterile PPLO broth was infused by similar method in one kid, which served as control. All infected animals showed swelling of vulva and milky vaginal discharge from day 2 post infection (DPI), and this persisted up to 7-10 d. The experiment was continued for $60 \mathrm{~d}$ during which one kid was sacrificed at every $10 \mathrm{~d}$ interval, however, one animal died on 12th DPI. The control kid was also killed at 60th DPI. Grossly, congestion, oedema, catarrhal exudate and nodular type of lesions were seen on the mucosa of vulva and vagina. Microscopically, all the infected kids developed lymphocytic vulvitis, vaginitis and cervicitis which increased in severity with time. $A$. oculi was reisolated from vaginal swabs of all the infected kids up to 60th DPI. The observations reported here indicate that $A$. oculi is pathogenic for female genital tract of goats and it causes granular vulvo-vaginitis (GVV).
\end{abstract}

Goats, A. oculi, vulva, vagina, cervix uteri, lymphoid follicles, granular vulvo-vaginitis

Acholeplasma oculi was first isolated from natural cases of keratoconjunctivitis in goats in Minnesota by Al-Aubaidi et al. (1973). According to these workers $A$. oculi proved to be highly pathogenic in natural as well as in experimental infections. Although subsequently $A$. oculi has also been isolated from naturally occurring genital lesions in goats, sheep and buffaloes (Kumar and Pathak 1978; Tiwana and Singh 1982; Katoch et al. 1982), its pathogenicity to female genital tract and its role in producing genital lesions has not been proven experimentally. Therefore the present work was undertaken to assess the pathogenicity of $A$. oculi to female genital tract of goats. Jones (1985) suggested that goats are better experimental animals and are potentially useful for screening the virulence of acholeplasmas.

\section{Materials and Methods}

Eight female kids aged 4 to 6 months were kept under observation for 7 days before starting the experiment. All were found to be healthy. No acholeplasma or mycoplasma were isolated from their vagina and no grossly visible vulvar lesions were detected during this period. The vaginal wall of the 7 kids was scarified with sterilised dental brush and then $2 \mathrm{ml}$ of a $48 \mathrm{~h}$ culture of A. oculi (19-L strain) at third passage level, containing $8 \times 10^{6} \cdot \mathrm{ml}^{-1}$ colony forming units (CFU) was inoculated into their vaginal canal with the help of sterilised pirettes. The vaginal canal of one kid was inoculated with sterilised PPLO broth and served as control. The experiment was continued for 60 days during which daily rectal temperature was recorded. Haematological values of all the experimental and one control kid were estimated at every tenth day interval (Schalm 1967). All the kids were observed daily to detect any gross abnormality as well as for abnormal discharge, 
if any from vulva and vagina. One animal was killed at every tenth day interval up to 60th day post-inoculation (DPI). However, one experimental animal died on 12th DPI. The control animal was also killed on 60th day of the experiment. The genital system and other organs were examined grossly and microscopically. For microscopic examination, 5 to $6 \mu$ thick paraff in sections were stained with haematoxylin and eosin. The vaginal swabs were cultured on PPLO medium for Acholeplasma/Mycoplasma isolation as described by Banerjee et al. (1979).

\section{Results}

The appetite and body temperature of all the kids remained unaffected. From 2 DPI the vulvar lips were slightly swollen and moderate milky white discharge was observed from vulva, which persisted for 7-10 days. There was slight gradual decrease in haemoglobin $(\mathrm{Hb})$ content. However, it was not statistically significant from control as well as pre-inoculation basal values. The total leucocyte counts (TLC) and differential leucocyte counts (DLC) also did not show any significant change.

Grossly, the mucosa of vulva and vagina of the kid, killed on 10th DPI was granular. Animal which died on 12th DPI revealed severe congestion of vulvar and vaginal mucosa and there was accumulation of thick caseated pus in the lumen of the anterior part of vagina. On 30th and 40th DPI, mucosa of vulva and posterior part of vagina was slightly congested, edematous and contained catarrhal exudate. On 50th DPI, the mucosa of vagina was thickened, rough and nodular. No visible gross lesion could be seen in the genitalia of the control kid. No gross pathological change was detected in other organs of both experimental and control kid. $A$. oculi was re-isolated from vaginal swabs of all the experimental kids upto 60th DPI.

Microscopically, lymphocytic vulvitis, vaginitis and cervicitis was seen in all the experimental kids and their extent and severity increased with increasing period after infection. Ten days after infection, the section of vulva showed infiltration of lymphocytes, plasma cells and a few neutrophils in the epithelial and subepithelial layers (Fig. 1). There were thick perivascular lymphocytic cuffings in the submucosa. Section of vagina showed infiltration of lymphocytes and plasma cells in the lamina propria, around blood vessels in the submucosa and in the muscular coat. Tunica serosa of the vaginal wall was also severely infiltrated with lymphocytes and plasma cells. Sections of os cervix showed infiltration of lymphocytes and plasma cells in the subepithelial layer and around the blood vessels in the muscular layer. The kid that died on 12 th DPI showed more severe lymphocytic vulvitis, vaginitis and cervicitis than seen on 10th DPI. The kid killed on 20th DPI showed more severe lymphocytic vulvitis, vaginitis and cervicitis than seen on 10th and 12th DPI. There was formation of lymphoid aggregates in the submucosa (Fig. 2) and hydropic degeneration of the lining epithelium. The kid killed on 30th DPI showed more severe changes than seen on 20th DPI, in addition, cystic dilatation of glands in the vagina was also seen. The kids killed on 40th, 50th and 60th DPI showed more severe lymphocytic vulvitis, vaginitis and cervicitis than seen at 30th DPI and their severity increased with increasing period of time. Formation of lymphoid follicles was seen in the lamina propria and submucosa of vulva, vagina, os cervix and cervical canal. The number and size of lymphoid follicles increased with increasing period of time (Figs. $3 \& 4$ ). The sections of uterus, oviduct and ovaries of all the experimental animals and the entire genital tract of the control animal did not show any pathological change. 


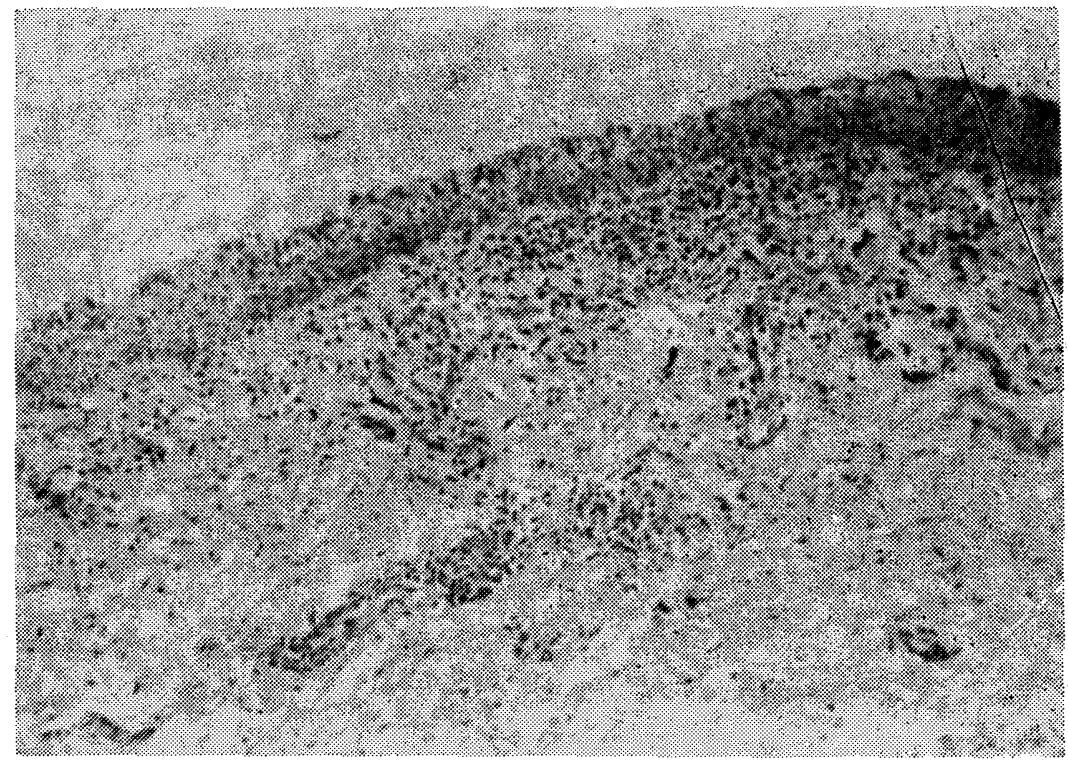

Fig. 1. Section of vulva of goat showing infiltration of lymphocytes in the subepithelial and epithelial layers and around the blood vessels, 10 days after infection with $A$. oculi. H.E. $\times 70$.

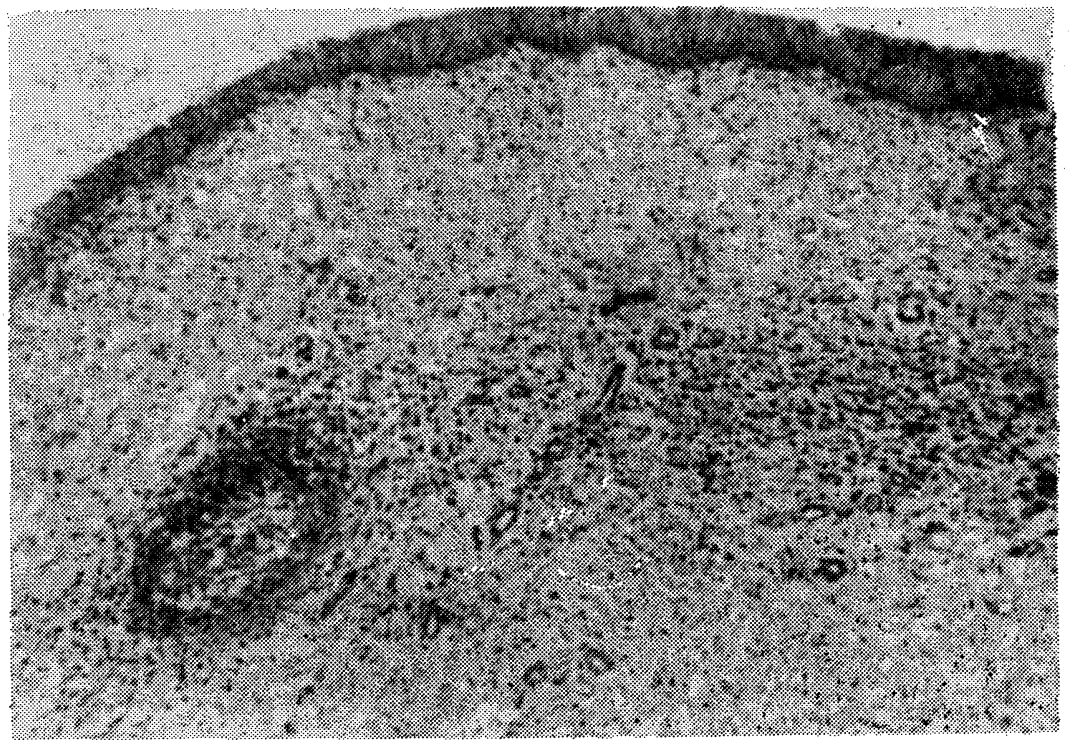

Fig. 2. Section of vagina of a goat killed 20 days after infection with $A$. oculi showing formation of lymphoid aggregate in the submucosa. H.E. $\times 70$. 


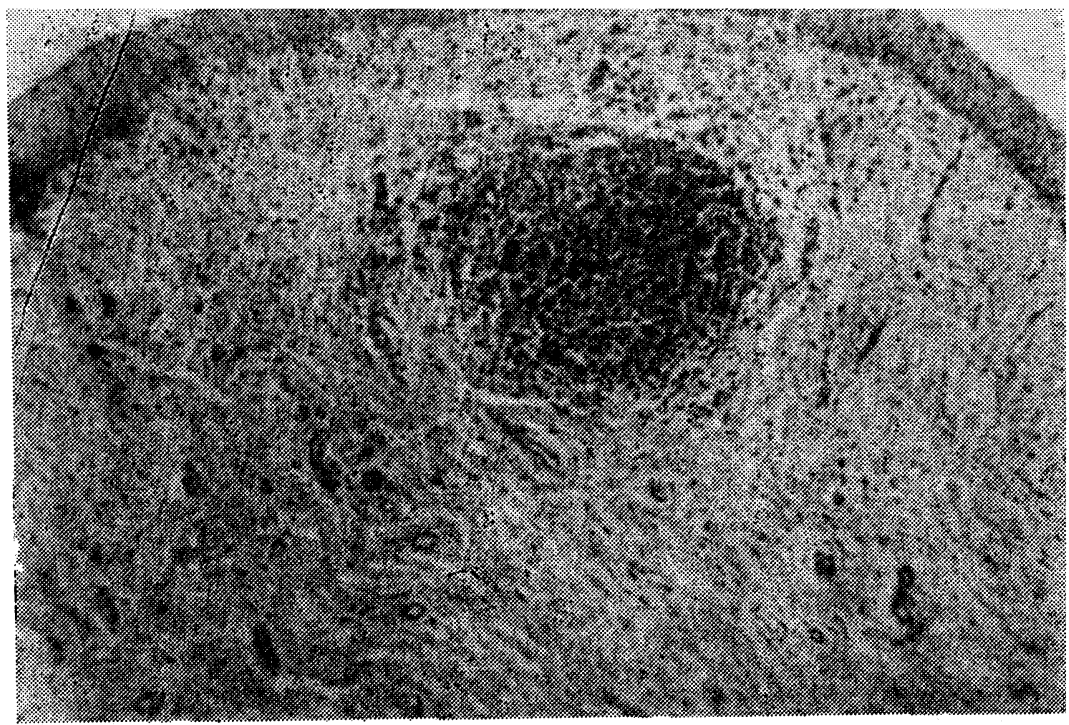

Fig. 3. Section of vagina of a goat killed 50 days after infection with $A$. oculi, showing large lymphoid follicle in the submucosa. H.E. $\times 70$.

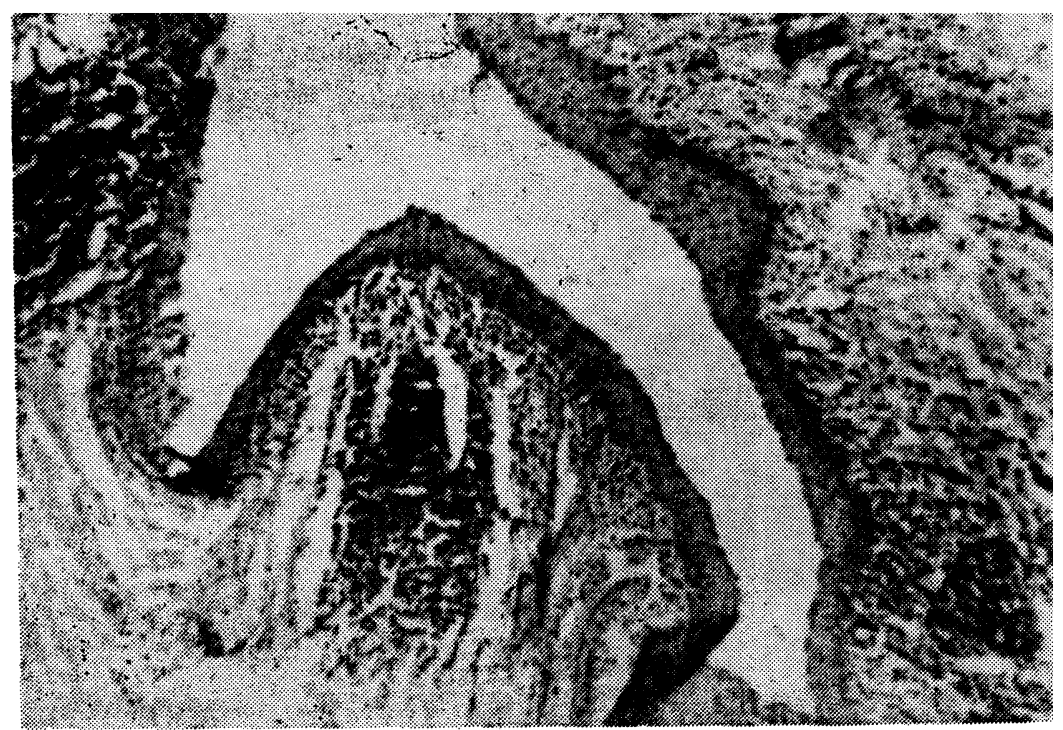

Fig. 4. Section of vulva of a goat killed 60 days after infection, showing numerous lymphoid follicles in the lamina propria. H.E. $\times 70$. 


\section{Discussion}

In the present study, infusion of $A$.oculi in the scarified vulvovaginal canal was done. During the experiment, none of the experimental kids showed rise in body temperature or any affect on the appetite. Haematological values did not reveal any significant change. These observations are in accordance with the findings of other workers on experimental genital mycoplasmosis in goats due to $M$. agalactiae (Singh et al. 1975) and $A$. laidlawii (Gupta et al. 1990) and in natural cases of vulvovaginitis in sheep due to $M$. capricolum and $A$. axanathum (Jones et al. 1983).

Clinical, gross and microscopic changes observed in the present study were similar to those reported in natural cases of GVV in goats due to $M$. agalactiae (Singh et al 1974), A. oculi and ovine serogroup 11 (Tiwana et al. 1984) and in experimentally induced GVV in goats due to $M$. agalactiae (Singh et al. 1975) and $A$. laidlawii (Gupta et al. 1990).

The vacuolar degeneration and exfoliation of epithelial cells lining the mucosa of vagina, observed in this study indicates that $A$. oculi damages the epithelial cells lining by producing the pathogenic toxin, lipoglycans (Gourlay and How ard 1982). Mycoplasmas and acholeplasmas have special affinity for secretory epithelial surfaces where they get intimately attached. This association between adhering mycoplasmas/acholeplasmas and the host cell provides a situation in which local concentration of toxic and acidic metabolite gets built up and cause cell damage. Thus the hydrogen peroxide, the respiratory end product, produced by organisms, alter the cell permeability without being destroyed by catalases and peroxidases, present in extracellular fluids (Razin 1978).

The infiltration of large numbers of lymphocytes and some plasma cells in the epithelial and subepithelial layers of the genital system, indicates that $A$. oculi organisms, like other mycoplasmas, mostly invites a cellular immune response (Bennett et al 1977).

A. oculi was re-isolated only from vaginal swabs of the experimental animals and not from blood, indicating that local infection of $A$. oculi remains confined to the genital system and does not cause systemic reaction, because the toxins of mycoplasmas/acholeplasmas are not highly invasive (Barile 1979). This observation is in accordance with the findings of Singh et al.(1975) and Gupta et al. (1990) in experimentally induced GVV in goats.

The observations made in the present study lead to the conclusion that $A$. oculi is pathogenic for goat genital tract and causes lymphocytic vulvitis, vaginitis and cervicitis.

\section{Patogenita Acholeplasma oculi pro pohlavní ústrojí u koz}

Ke studiu patogenity Acholeplasma oculi pro samičí pohlavní ústroji bylo použito 8 koziček. Dva ml kultury $A$. oculi (kmen 19-L) s obsahem $8 \cdot 10^{6} \cdot \mathrm{ml}^{-1} \mathrm{CFU}$ byly inokulovány do skarifikované sliznice vulvy a vaginy 7 kủzlat, $2 \mathrm{ml}$ sterilního PPLO bujonu bylo infundováno osmé, kontrolní kozičce. U všech infikovaných zviřrat došlo $\mathrm{k}$ edému vulvy a mléčnému výtoku $\mathrm{z}$ vaginy 2 dny po infekci, trvajícímu 7-10 dnủ. Pokus trval $60 \mathrm{~d}$ a v $10-\mathrm{d}$ intervalech byla kủzlata po jednom utrácena ( 1 zviŕe uhynulo 12. d po infekci). Kontrolní kozička byla rovněž utracena 60. dne. Na sliznici vulvy a vaginy byly zjištěny edémy, katarální exudáty a no- 
dulární léze. U všech zviřat byl mikroskopický nález lymfocytárni zánět vulvy a vaginy i krčku děložního. Tyto nálezy nabývaly na intenzitě s počtem dní po infekci. $A$. oculi byla reizolována $\mathrm{z}$ vaginálních nátěrů všech infikovaných zviřat. $\mathrm{Z}$ pokusu vyplývá že $A$. oculi je patogenní pro samičí pohlavní aparát koz a způsobuje u nich granulární vulvovaginitidu (GVV).

\section{Патогенность Acholeplasma осuli для половых органов козы}

Для исспедования патогенности Acholeplasma oculi по отношению к половым органам самок использовали 8 коз. Два миллилитра культуры A. oculi (штамм 19-L) с содержанием 8.10 .мл-1 CFU инокулировали в скарифицированную слизистую вульвы и влагалища 7 козлят, 2 мл стерильного PPLO инфундировали босьмой, контрольной козочке. У всех инфицированных животных возникли отечность вүльвы и мопочные выделения из влагалища спустя двое сүток после инфекции, длящейся 7-10 суток. Эксперимент длился 60 сүток и в интервалах 10 сүток козлят по одиночке умерщвляли (летальный исход 1 животного имел место на 12 сутки после инфекции). Контрольную козочку также умерщвили на 60 сутки. На слизистых вульвы и влагалища выявили отеки, катаральные экссудаты и нодулярные повреждения. Микроскопический анализ у всех животных сводился к лимфоцитарному воспалению вульвы и влагалища, а также шейки матки. Данные анализы отличались интенсивностью с увеличивающимся числом суток после инфекции. Реизолировали A. oculi из влагалищных мазков всех инфицированных животных. Из эксперимента вытекает, что $А$. oculi является патогенной для полового устройства коз, вызывая у них грануляционный вульвовагинит (ГВВ).

\section{References}

Al-AUBAIDI, J. M.-DARDIRI, A. H.-MUSCOPLATT, C. C.-M'CAULEY, E. H.: Identification and characterization of Acholeplasma oculi spec. nov. from the eyes of goats with keratoconjuctivitis. Cornell Vet. 63, 1973: 117-129

BANERJEE, M.-SINGH, N.-GUPTA, P. P.: Isolation of mycoplasmas and acholeplasmas from pneumonic lesions in sheep and goats in India. Zbl. Vet. Med. B., 26, 1979: 689-695

BARILE, M. F.: Mycoplasma-tissue cell interactions. In: the Mycoplasmas, Vol. 11. Edited by Barile, M. F. and Razin, S. Academic Press, N. Y. 1979: 425-464

BENNETT, R. H. - CARROLL, E. J.-JASPER, D. E.: Skin Senstivity reactions in calves inoculated with Mycoplasma bovis antigens; humoral and cell mediated responses. Am. J. Vet. Res. 38, 1977: $1721-1730$

GOURLAY, R. N. - HOWARD, C. J.: Respiratory mycoplasmosis. Adv. Vet. Sci. Comp. Med. 26, 1982: 289-332

GUPTA, P. P. - SINGH, A.-BANGA, H. S.-SINGH, S. P.: Pathology of the genital tract of goats experimentally infected with A. laidlawii. Indian Vet. J. 67, 1990: 871-872

JONES, C. E.: The Pathogenicity of some ovine or caprine mycoplasmas in the lactating mammary gland of sheep and goats. J. Comp. Path. 95, 1985: 305-318

JONES, G. E.-RAE, A. G. - HOLMES, R. G. - LISTER, S. A.-JONES, J. M. W.-GRATER, G. S. - RICHARDS, N.: Isolation of exotic mycoplasmas from sheep in England. Vet. Rec. 113, 1983: 540

KATOCH, R. C. - SODHI S. S. - BAXI, K. K.: Isolation and characterisation of some members of order Mycoplasmatales from female genital tract of buffaloes. Indian J. Comp. Microbiol. Imm. \& Infect. Dis. 3, 1982: 128-137 
KUMAR, N. - PATHAK, R. C.: Isolation and characterisation of some members of Mycoplasma and Acholeplasma from uterus of sheep and goats. Ind. J. Expt. Biol. 16, 1978: 1 011-1 013

RAZIN, S.: The Mycoplasmas. In Microbiol. Rev. 42, 1978: 414-470.

SCHALM, O. W.: The Veterinary Haematology. 2nd ed. Lea and Febiger, Philadelphia. 1967

SINGH, N.-RAJYA, B. S.-MOHANTY, G. C.: Granular vulvovaginitis (GVV) in goats associated with Mycoplasma agalactiae. Cornell Vet. 64, 1974: 435-442

SINGH, N.-RAJYA, B. S. - MOHANTY, G. C.: Pathology of Mycoplasma agalactiae induced granular vulvovaginitis (GVV) in goats. Cornell Vet. 65, 1975: 363-373

TIWANA, J. S.-SINGH, N.: Isolation of A. oculi from genital lesions in sheep. Vet. Rec. 111, 1982: 417

TIWANA, J. S. - SINGH, N. - KWATRA, M. S.: Isolation of Mycoplasma and Acholeplasma from vulvovaginitis in goats. Indian J. Comp. Microbiol. Immun. \& Infect. Dis. 5, 1984: $17-19$ 